Педагогика

УДК 372.878

Ли Цзылун

Российский государственный педагогический университет имени А. И. Гериена

\title{
АНАЛИЗ РАЗВИТИЯ МУЗЫКАЛЬНОГО ВООБРАЖЕНИЯ СТУДЕНТОВ В ПРОЦЕССЕ ОБУЧЕНИЯ ИГРЕ НА САКСОФОНЕ
}

Аннотация. Искусство, это сочиальная идеология, которая использует образы для отражения реальности, но более типичные, чем реальность. Тогда искусство музыки - это вид искусства, используемый для слуховых образов, состоящих из организованных звуков для выражения мьсллей и чувств людей и социальной реальности жизни. При преподавании музыки в школах развитие музыкального воображения учащихся может позволить им лучше оценить чувства и настроения, выраженные в музыкальных произведениях, глубоко оченить творческую среду автора, а также творческое состояние души, и в то же время интегрировать свои собственные эмоции и понимание в процессе исполнения произведений. Тон саксофона разнообразен, он может играть как красивые и глубокие произведения, так и напряжсенные произведения, и студенты могут умеренно выражать свое воображение в процессе игры, что может не только улучшить их собственную музыкальную 
International Electronic Scientific Journal “Science Online” http://nauka-online.com/

грамотность, но и способствовать развитию всестороннего музыкального образования.

Ключевые слова: музыкаьное обучение, саксофон, воображение, студентыл.

Способы развития музыкального воображения учащихся при обучении игре на саксофоне:

- Развитие мыслительных способностей учащихся

Хорошие привычки могут способствовать улучшению способностей. Но привычки нельзя сформировать сразу, их нужно формировать постепенно, день за днем и месяц за месяцем. В процессе обучения игре на саксофоне преподаватели должны уделять внимание руководству учениками и развитию у них способности к самостоятельному мышлению.[1] В процессе ознакомления с музыкальным репертуаром саксофона многократно повторяйте мелодию, чтобы направить мыслительные способности учащихся в процессе прослушивания, чтобы развить привычку мыслить в процессе непрерывного обучения. Получив способность мыслить самостоятельно, учащиеся смогут полностью развить свое воображение через собственное мышление при восприятии мелодий [2].

- Помочь студентам прочувствовать работу наизусть

Чтобы по-настоящему ощутить очарование музыки, ее нужно слушать наизусть. При обучении игре на саксофоне преподаватели должны 
сосредоточиться на том, чтобы подтолкнуть учеников слушать каждое произведение сердцем и чувствовать эмоции, передаваемые произведением. Благодаря постоянному руководству учителя, он может помочь ученикам понять работу. В преподавании музыки, сосредоточение внимания на понимании чувств, которые должны быть переданы музыкальными произведениями, может позволить учащимся в полной мере оценить очарование и содержание музыкальных произведений.

- Развитие творческого мышления

Образ мышления каждого студента, его учебный и жизненный опыт очень разные, и поэтому у них будут разные мнения о понимании музыкальных произведений. В процессе преподавания музыки учителя должны направлять учеников на выражение собственного мнения путем самостоятельного мышления и включения собственных взглядов и идей в исполнение музыки, чтобы они могли воссоздать музыкальные произведения и проявить свою уникальную чувствительность и творческие способности. Благодаря пониманию разнообразного репертуара саксофона и развитию творческого мышления, студенты смогут в полной мере проявить свои выразительные способности.

Музыкальное воображение имеет большое значение для сочинения и исполнения музыки студентами. Благодаря постоянному руководству преподавателя, в процессе непрерывного изучения исполнительского репертуара саксофона, можно развить у студентов способность к 
International Electronic Scientific Journal "Science Online" http://nauka-online.com/

самостоятельному мышлению, способность чувствовать и творчески мыслить. Благодаря этим способностям, музыкальное воображение учащихся развивается, чтобы они могли полностью интегрировать свои собственные идеи в создание и восприятие музыки.

Студенты смогут полностью интегрировать свои собственные эмоции в восприятие музыки.

\section{Литература}

1. Ли Сяоди. Развитие воображения в преподавании музыки на саксофоне / Ли Сяоди // китайское оборудование для образовательных технологий. 2014. C. $124-126$.

2. Сун Хайци. Развитие музыкального воображения при обучении игре на саксофоне / Сун Хайци // Еженедельник "Преподавание". 2015. 